\title{
FAKTOR-FAKTOR YANG MEMPENGARUHI PENERIMAAN OPINI AUDIT GOING CONCERN PADA PERUSAHAAN PUBLIK SEKTOR MANUFAKTUR
}

\author{
YULIUS KURNIA SUSANTO \\ STIE Trisakti \\ yulius@stietrisakti.ac.id
}

\begin{abstract}
The purpose of the study is to investigate over the acceptance of going concern audit opinion which can be performed by observing company's financial condition, current ratio, quick ratio, cash flow from operations, return on assets, debt to equity, long term debt to total assets, debt to total assets, audit quality, prior audit opinion, debt default and opinion shopping. Samples are obtained by sampling purposive method. Data for this study comprises of the information from the financial statement of the public manufacturing companies in Indonesia over the four year period 2005 until 2008, and the result obtained 260 observations. The logistic regression used to examine the factors that are predicted to affect the probability of acceptance of going concern audit opinion. The result of this research is that company's financial condition (Revised Altman Model), return on assets, debt to total assets and prior audit opinion are significantly affect the probability of acceptance of going concern audit opinion. On the other hand, current ratio, quick ratio, cash flow from operations, debt to equity, long term debt to total assets, audit quality, debt default and opinion shopping, do not so.
\end{abstract}

Keywords: Going concern audit opinion, company's financial condition, financial ratio, audit quality, prior audit opinion, debt default and opinion shopping. 


\section{PENDAHULUAN}

Auditor mempunyai peranan penting dalam menjembatani antara kepentingan investor sebagai pengguna laporan keuangan dan kepentingan perusahaan sebagai penyedia laporan keuangan. Data perusahaan akan lebih mudah dipercaya oleh investor dan pemakai laporan keuangan lainnya apabila laporan keuangan tersebut mencerminkan kinerja dan kondisi perusahaan dan telah mendapat pernyataan wajar dari auditor. Pernyataan auditor diungkapkan melalui opini audit. Dengan menggunakan laporan keuangan yang telah diaudit, para pemakai laporan keuangan dapat mengambil keputusan dengan benar sesuai dengan kenyataan yang sesungguhnya.

Dalam menentukan opini audit suatu perusahaan auditor juga harus memperhatikan likuiditas, profitabilitas dan solvabilitas perusahaan tersebut. Likuiditas menunjukkan kemampuan perusahaan untuk membayar kewajiban jangka pendek dengan aset-aset likuid yang dimiliki perusahaan. Profitabilitas menunjukkan keuntungan yang diperoleh perusahaan selama perioda tertentu. Solvabilitas menunjukkan kemampuan perusahaan untuk membayar kewajibannya dalam jangka panjang. Melalui perhitungan rasiorasio ini auditor dapat mengetahui tentang baik atau buruknya kinerja suatu perusahaan.

Motivasi penelitian ini adalah topik mengenai tanggung jawab auditor dalam mengungkapkan masalah going concern masih menarik untuk diteliti dan mengingat pentingnya laporan keuangan auditan bagi calon investor sebagai acuan pengambilan keputusan sebelum berinvestasi di pasar modal. Mengingat kasus Enron beberapa tahun lalu, banyak investor terjebak atas laporan keuangan yang disajikan oleh Enron, maka penulis tertarik untuk meneliti tentang opini audit yang dikeluarkan oleh auditor.

Masalah going concern suatu perusahaan merupakan hal yang sangat penting untuk diketahui dan diungkapkan, agar perusahaan dapat mengambil tindakan selanjutnya dan pertimbangan keputusan yang tepat untuk mempertahankan kelangsungan hidup usahanya sehingga terhindar dari kebangkrutan. Tujuan yang hendak dicapai dari penelitian ini adalah untuk mendapatkan bukti empiris bahwa (1) Kondisi keuangan perusahaan yang buruk membuat auditor cenderung memberikan opini audit going concern; (2) Current ratio, Quick ratio, Cash flow from operations dan Return on assets yang rendah membuat auditor cenderung memberikan opini audit going concern; (3) Debt to equity, Long term debt to total assets dan Debt to total assets yang tinggi membuat auditor cenderung memberikan opini audit going concern; (4) KAP non big four cenderung memberikan opini audit going concern; (5) Auditor cenderung memberikan opini audit going concern 
yang sama dengan opini audit tahun sebelumnya; (6) Debt default membuat auditor cenderung memberikan opini audit going concern; (7) Perusahaan yang melakukan opinion shopping cenderung menghindari pemberian opini audit going concern.

Penelitian ini disusun dengan urutan penulisan sebagai berikut pertama, pendahuluan menjelaskan mengenai latar belakang masalah, tujuan penelitian dan organisasi penulisan. Kedua, menguraikan teori dan hasil penelitian sebelumnya sebagai dasar pengembangan hipotesis. Ketiga, metoda penelitian terdiri atas pemilihan sampel dan pengumpulan data, definisi operasional dan pengukuran variabel. Keempat, hasil penelitian yang berisi hasil dan interpretasi pengujian hipotesis. Terakhir, penutup yang berisi simpulan, keterbatasan penelitian dan saran untuk peneltian selanjutnya.

\section{RERANGKA TEORITIS DAN PENGEMBANGAN HIPOTESIS}

\section{Teori Keagenan}

Jensen dan Meckling (1976) menggambarkan hubungan agensi sebagai suatu kontrak di bawah satu atau lebih prinsipal yang melibatkan agen untuk melaksanakan beberapa layanan bagi mereka dengan melakukan pendelegasian wewenang pengambilan keputusan kepada agen. Baik prinsipal maupun agen diasumsikan orang ekonomi rasional dan semata-mata termotivasi oleh kepentingan pribadi. Shareholders atau prinsipal mendelegasikan pembuatan keputusan mengenai perusahaan kepada manajer atau agen. Bagaimanapun juga, manajer tidak selalu bertindak sesuai keinginan shareholders, sebagian dikarenakan oleh adanya moral hazard.

Dibutuhkan pihak ketiga yang independen sebagai mediator pada hubungan antara prinsipal dan agen. Pihak ketiga ini berfungsi untuk memonitor perilaku manajer (agen) apakah sudah bertidak sesuai dengan keinginan prinsipal. Auditor adalah pihak yang dianggap mampu menjembatani kepentingan pihak prinsipal (shareholders) dengan pihak manajer (prinsipal) dalam mengelola keuangan perusahaan (Setiawan 2006). Auditor melakukan fungsi monitoring pekerjaan manajer melalui sebuah sarana yaitu laporan tahunan. Tugas auditor adalah memberikan opini atas laporan keuangan tersebut, mengenai kewajarannya. Selain itu, auditor saat ini juga harus mempertimbangkan akan kelangsungan hidup perusahaan.

\section{Kemampuan Perusahaan Mempertahankan Kelangsungan Hidup}

Auditor sebagai pihak yang independen, bertanggungjawab mengevaluasi apakah terdapat kesangsian terhadap kelangsungan hidup perusahaan 
yang diperiksanya. Auditor dapat mengidentifikasi informasi mengenai kondisi tertentu yang menunjukkan adanya kesangsian tetang kemampuan perusahaan untuk melangsungkan hidupnya dalam jangka waktu tertentu (tidak lebih dari satu tahun sejak tanggal laporan keuangan yang sedang diaudit) (IAPI 2001, seksi 341). Contoh kondisi tersebut adalah: (2) Tren negatif, sebagai contoh: kerugian operasi yang berulang terjadi, kekuarangan modal kerja, aliran kas negatif dari kativitas operasi, rasio keuangan yang jelek; (2) Petunjuk lain tentang kemungkinan kesulitan keuangan, sebagai contoh: kegagalan dalam memenuhi kewajiban atau perjanjian serupa, penunggakan pembayarna dividen, penolakan oleh pemasok terhadap pengajuan pembelian kredit, restrukturisasi utang, kebutuhan mencari sumber pendanaan baru atau menjual sebagian besar aktiva; (3) Masalah intern, sebagai contoh: pemogokan kerja atau keretakan hubungan antara perusahaan dengan buruh, ketergantungan besar atas kesuksesan proyek tertentu, komitmen jangka panjang yang tidak bersifat ekonomis, kebutuhan yang signifikan untuk memperbaiki kegiatan operasi perusahaan; (3) Masalah luar perusahaan, sebagai contoh: pengaduan gugatan pengadilan, keluarnya undang-undang atau peraturan lain yang kemungkinan membahayakan kemapuan perusahaaan untuk beroperasi, kehilangan franchise, lisensi atau paten penting, kehilangan pelanggan atau pemasok utama, kerugian akibat bencana seperti gempa bumi dan banjir yang tidak diasuransikan atau diasuransikan dengan pergantian atau pertanggungan yang tidak memadai.

\section{Kondisi Keuangan dan Opini Audit Going Concern}

Tingkat kesehatan perusahaan dapat dilihat dari kondisi keuangan perusahaan. Pada perusahaan yang kondisi keuangannya baik maka auditor cenderung untuk tidak mengeluarkan opini audit going concern (Ramadhany 2004). Hal ini didukung oleh Carcello et al. (2000) yang menyebutkan bahwa kondisi keuangan perusahaan yang terganggu maka kemungkinan perusahaan menerima opini audit going concern. Pendapat tersebut juga didukung oleh Setyarno et al. (2007), Santoso dan Wedari (2007) serta Rudyawan dan Badera (2009) yang menyatakan bahwa semakin baik kondisi keuangan perusahaan semakin kecil kemungkinan auditor memberikan opini audit going concern. Auditor hanya memberikan opini audit going concern jika perusahaan mengalami kesulitan melanjutkan kelangsungan usahanya. Hipotesis yang diajukan adalah:

$\mathrm{H}_{1}$ Kondisi keuangan perusahaan yang buruk membuat auditor cenderung memberikan opini audit going concern. 


\section{Rasio Keuangan dan Opini Audit Going Concern}

Petronela (2004) meneliti tentang pemberian opini audit going concern dengan menggunakan rasio keuangan profitabilitas dan leverage. Hasil penelitian tersebut memperkuat penelitian sebelumnya, yaitu variabel profitabilitas berpengaruh signifikan sedangkan leverage tidak. Penelitian tersebut membuktikan bahwa auditor sebelum mengeluarkan opini audit perlu mempertimbangkan profitabilitas perusahaan yang diaudit, sedangkan kemampuan perusahaan untuk membayar hutang tidak terlalu diperhatikan oleh auditor dalam memberikan opini audit.

Dalam hubungannya dengan likuiditas, semakin kecil current ratio, perusahaan kurang likuid sehingga tidak dapat membayar para krediturnya, maka auditor kemungkinan memberikan opini audit dengan going concern. Tidak jarang perusahaan yang secara konsisten mengalami kerugian operasi mempunyai working capital yang sangat kecil bila dibandingkan dengan total aset.

Petronela (2004) menyatakan bahwa tingginya debt to equity mencerminkan tingginya risiko keuangan perusahaan. Risiko keuangan perusahaan yang tinggi mengindikasikan bahwa perusahaan mengalami kesulitan keuangan. Hal ini merupakan berita buruk yang akan mempengaruhi kondisi perusahaan di mata masyarakat. Debt to equity yang tinggi menjadi perhatian auditor karena debt to equity yang tinggi mengindikasikan bahwa perusahaan tidak dapat mempertahankan kelangsungan hidupnya.

Perusahaan dengan nilai aset lebih kecil daripada kewajibannya akan menghadapi bahaya kebangkrutan. Simpulan ini didukung oleh Chen dan Church (1992) yang mengkaji kemampuan variabel kegagalan pembayaran utang untuk menjelaskan opini audit. Semakin tinggi utang perusahaan terhadap kemapuan perusahaan untuk membayarnya, semakin buruk kinerja perusahaan. Hal ini dapat menimbulkan ketidakpastian kelangsungan hidup perusahaan dan berpeluang untuk mendapatkan opini audit going concern (Rudyawan dan Badera 2009). Berdasarkan hasil penelitian Petronela (2004) menyatakan bahwa debt to equity perusahaan kurang dipertimbangkan oleh auditor dalam memberikan opini audit atas laporan keuangan perusahaan yang diaudit.

Berdasarkan hasil pengujian yang dilakukan oleh Komalasari (2004) diperoleh bahwa profitabilitas cenderung mempengaruhi auditor dalam pemberian opini audit. Hasil penelitian ini konsisten dengan hasil penelitian Petronela (2004) yang menyatakan bahwa profitabilitas perusahaan dipertimbangkan oleh auditor dalam memberikan opini audit atas laporan keuangan perusahaan yang diaudit. Hasil penelitian ini juga konsisten dengan hasil 
penelitian Hani et al. (2003) yang menyatakan bahwa profitabilitas mempunyai pengaruh yang kuat terhadap opini audit.

Dalam hasil pengujian Hani et al. (2003) dikatakan bahwa rasio keuangan tidak dapat dijadikan tolok ukur yang pasti untuk menentukan going concern atau kelangsungan hidup suatu perusahaan. Namun rasio keuangan dapat menjadi alat bantu dalam pengukuran kesehatan perusahaan dalam kelangsungan hidupnya. Hipotesis yang diajukan adalah:

$\mathrm{H}_{2}$ Current ratio yang rendah membuat auditor cenderung memberikan opini audit going concern.

$\mathrm{H}_{3}$ Quick ratio yang rendah membuat auditor cenderung memberikan opini audit going concern.

$\mathrm{H}_{4}$ Cash flow from operations yang rendah membuat auditor cenderung memberikan opini audit going concern.

$\mathrm{H}_{5}$ Return on assets yang rendah membuat auditor cenderung memberikan opini audit going concern.

$\mathrm{H}_{6}$ Debt to equity yang tinggi membuat auditor cenderung memberikan opini audit going concern.

$\mathrm{H}_{7}$ Long term debt to total assets yang tinggi membuat auditor cenderung memberikan opini audit going concern.

$\mathrm{H}_{8}$ Debt to total assets yang tinggi membuat auditor cenderung memberikan opini audit going concern.

\section{Kualitas Audit dan Opini Auditor Going Concern}

Ramadhany (2004) menyatakan bahwa perusahaan audit skala besar memiliki insentif yang lebih untuk menghindari kritikan kerusakan reputasi dibandingkan pada perusahaan audit skala kecil. Perusahaan audit besar juga lebih cenderung untuk mengungkapkan masalah-masalah yang ada karena mereka lebih kuat menghadapi risiko proses pengadilan. Argumen di atas berarti bahwa perusahaan audit besar memiliki insentif lebih untuk mendeteksi dan melaporkan masalah going concern kliennya.

Berdasarkan hasil penelitian Komalasari (2004) mengenai kualitas auditor yang diproksikan dengan skala auditor (besaran KAP) diperoleh hasil bahwa kualitas auditor lebih cenderung mempengaruhi auditor dalam memberikan opini audit dengan going concern berhasil ditolak. Hal ini berarti bahwa perusahaan yang menggunakan jasa KAP yang berkualitas tidak dapat menentukan apakah perusahaan akan mendapat unqualified opinion atau tidak. Hasil penelitian ini konsisten dengan hasil penelitian yang dilakukan oleh Setyarno et al. (2007), Santoso dan Wedari (2007) serta Ramadhany (2004). Kantor Akuntan Publik baik big four maupun non big four 
akan selalu bersikap obyektif dalam memberikan pendapat. Jika perusahaan mengalami keraguan dalam meneruskan usahanya maka akan diberikan opini audit going concern. Hal ini berbeda dengan hasil penelitian Rahayu (2007), yaitu kualitas auditor mempengaruhi pemberian opini audit going concern. KAP big four cenderung memberikan opini wajar daripada KAP non big four yang cenderung memberikan opini audit going concern. Hipotesis yang diajukan adalah:

$\mathrm{H}_{9}$ KAP non big four cenderung memberikan opini audit going concern.

\section{Opini Audit Tahun sebelumnya dan Opini Audit Going Concern}

Beberapa penelitian menemukan bahwa auditor lebih sering mengeluarkan opini audit going concern jika opini tahun sebelumnya adalah opini going concern. Hal ini dapat dikatakan bahwa opini audit tahun sebelumnya berpengaruh terhadap pemberian opini audit going concern. Penelitian Setyarno et al. (2007), Santoso dan Wedari (2007), Rahayu (2007) dan Ramadhany (2004) memperkuat bukti mengenai opini audit going concern yang diterima tahun sebelumnya dengan opini audit going concern tahun berjalan. Ada hubungan positif yang signifikan antara opini audit going concern yang diterima tahun sebelumnya dengan opini audit going concern tahun berjalan. Apabila pada tahun sebelumnya auditor telah menerbitkan opini audit going concern, semakin besar kemungkinan auditor untuk menerbitkan kembali opini audit going concern pada tahun berikutnya. Hal ini menunjukkan bahwa auditor dalam memberikan opini audit akan mempertimbangkan opini audit tahun sebelumnya. Hipotesis yang diajukan adalah:

$\mathrm{H}_{10}$ Auditor cenderung memberikan opini audit going concern yang sama dengan opini audit tahun sebelumnya.

\section{Debt Default dan Opini Audit Going Concern}

Praptitorini dan Januarti (2007) serta Ramadhany (2004) menunjukkan bahwa variabel debt default signifikan berpengaruh terhadap penerimaan opini going concern. Hasil penelitian ini konsisten dengan penelitian terdahulu yang dilakukan oleh Chen dan Church (1992), Mutchler et al. (1997) serta Carcello et al. (1992). Dalam penelitian Chen dan Church (1992) menemukan bukti yang kuat antara pemberian status debt default dengan masalah going concern.

Kegagalan dalam memenuhi kewajiban hutang dan atau bunga merupakan indikator going concern yang banyak digunakan oleh auditor dalam menilai kelangsungan hidup perusahaan. Dalam masa krisis, dimulai tahun 1997, terjadi fluktuasi nilai tukar mata uang rupiah. Hal ini mengakibatkan 
jumlah hutang perusahaan dalam mata uang asing meningkat secara signifikan, disamping itu banyak perusahaan yang mengalami rugi operasi dan realisasi penjualan pun anjlok. Akhirnya keadaan ini mempengaruhi kemampuan perusahaan dalam memenuhi kewajiban pokok dan beban bunga. Hipotesis yang diajukan adalah:

$\mathrm{H}_{11}$ Debt default membuat auditor cenderung memberikan opini audit going concern.

\section{Opinion Shopping dan Opini Audit Going Concern}

Penelitian dengan topik opini going concern terus dilakukan. Perkembangan baru mengenai topik ini adalah adanya fenomena opinion shopping (auditor switching). Lennox (2000) menggunakan model pelaporan audit untuk memprediksi opini yang tidak diteliti dan menguji dampaknya pada pergantian auditor. Hasil dari metode ini berkesimpulan bahwa perusahanperusahaan di Inggris melakukan praktik opinion shopping.

Untuk penelitian di Indonesia oleh Praptitorini dan Januarti (2007) menunjukkan bahwa perusahaan cenderung menggunakan auditor independen yang sama apapun opini audit yang diberikan, karena perusahaan enggan untuk mengganti auditor independen. Hal ini terlihat dari terbitnya peraturan tentang lamanya penggunaan auditor independen selama tiga tahun dan Kantor Akuntan Publik selama lima tahun. Bukti empiris ini menunjukkan indikasi kurangnya independensi auditor di Indonesia. Hipotesis yang diajukan adalah:

$\mathrm{Ha}_{12}$ Perusahaan yang melakukan opinion shopping cenderung menghindari pemberian opini audit going concern.

\section{METODA PENELITIAN}

\section{Pemilihan Sampel dan Pengumpulan Data}

Sampel yang digunakan peneliti adalah perusahaan manufaktur yang terdapat di Bursa Efek Indonesia (BEI) pada tahun 2005 sampai dengan 2008. Dari 140 perusahaan manufaktur yang terdapat di BEI terdapat 65 perusahaan yang memenuhi kriteria dalam penelitian ini. 


\section{Tabel 1 Prosedur Pemilihan Sampel Penelitian}

\begin{tabular}{|c|c|}
\hline Keterangan & Jumlah \\
\hline $\begin{array}{l}\text { Perusahaan manufaktur yang terdapat di BEI secara konsisten pada } \\
\text { tahun } 2005 \text { sampai } 2008\end{array}$ & 140 \\
\hline $\begin{array}{l}\text { Perusahaan yang Laporan Keuangan nya tidak berakhir per } 31 \\
\text { Desember secara konsisten selama perioda penelitian. }\end{array}$ & (1) \\
\hline $\begin{array}{l}\text { Perusahaan yang Laporan Keuangan nya tidak menggunakan mata } \\
\text { uang Rupiah secara konsisten selama perioda penelitian }\end{array}$ & (6) \\
\hline $\begin{array}{l}\text { Perusahaan yang tidak mengalami kesulitan keuangan (financial } \\
\text { distress) atau dengan kata lain perusahaan yang menghasilkan laba } \\
\text { secara konsisten selama perioda penelitian. Kategori Financial } \\
\text { Distress yang digunakan adalah perusahaan yang memiliki laba } \\
\text { setelah pajak atau aliran kas operasi yang negatif. }\end{array}$ & $(53)$ \\
\hline Perusahaan yang Laporan Auditor Independen nya bukan & $(8)$ \\
\hline $\begin{array}{l}\text { Unqualified Opinion dan Unqualified Opinion with Explanatory } \\
\text { Paragraph mengenai Going Concern secara konsisten selama } \\
\text { perioda penelitian. }\end{array}$ & \\
\hline $\begin{array}{l}\text { Perusahaan yang datanya tahun } 2008 \text { belum terupload pada website } \\
\text { www.idx.co.id }\end{array}$ & (7) \\
\hline Perusahaan yang memenuhi kriteria sampel & 65 \\
\hline
\end{tabular}

Data yang digunakan dalam penelitian ini adalah data sekunder. Data sekunder adalah data penelitian yang diperoleh peneliti secara tidak langsung melalui media perantara, yaitu laporan keuangan perusahaan manufaktur yang terdapat di BEI. Data mengenai kondisi keuangan, rasio-rasio keuangan (liquidity ratio, Long Term Debt and Solvency Ratio dan Profitability Ratio), Kantor Akuntan Publik yang mengaudit perusahaan, opini audit tahun sebelumnya, debt default dan Opinion shopping diperoleh dari ringkasan kinerja, laporan keuangan tahun dan catatan atas laporan keuangan tahun 2005 sampai 2008.

\section{Definisi Operasional dan Pengukuran Variabel}

Opini audit merupakan pendapat yang diberikan oleh auditor atas laporan keuangan yang diauditnya. Dalam memberikan opini atas laporan keuangan perusahaan, auditor wajib memberikan pernyataan atas kelangsungan hidup perusahaan di masa yang akan datang (going concern). Menurut Komalasari (2004), variabel ini diukur menggunakan skala nominal dengan menggunakan variabel dummy, yaitu: Opini audit unqualified dengan going concern audit report (GCAR) diberi nilai " 1 ". Opini audit unqualified tanpa going concern audit report (Non-GCAR) diberi nilai " 0 ". 
Kondisi keuangan perusahaan menggambarkan tingkat kesehatan perusahaan. Pada kondisi keuangan yang tidak sehat banyak ditemukan indikator masalah going concern (Ramadhany 2004). Kondisi perusahaan diukur dengan menggunakan Revised Altman Model (1993), model yang dikembangkan sebelumnya mengalami revisi yang tujuannya adalah agar model prediksinya tidak hanya digunakan pada perusahaan manufaktur tetapi juga dapat digunakan untuk perusahaan selain manufaktur. Model Revisi Altman (1993) adalah sebagai berikut:

$$
\begin{aligned}
& Z^{\prime}=0.717 Z_{1}+0.874 Z_{2}+3.107 Z_{3}+0.420 Z_{4}+0.998 Z_{5} \\
& Z_{1}=\text { working capital/total asset } \\
& Z_{2}=\text { retained earnings/total asset } \\
& Z_{3}=\text { earnings before interest and taxes/total asset } \\
& Z_{4}=\text { book value of equity/book value of debt } \\
& Z_{5}=\text { sales/total asset }
\end{aligned}
$$

Berdasarkan nilai Z' tersebut, apabila nilai Z' di atas 2,9 maka perusahaan digolongkan sebagai perusahaan sehat dan diberi nilai 1; Nilai $Z$ ' di antara 1,2 sampai dengan 2,9 maka kondisi perusahaan tidak diketahui sehat atau tidak dan diberi nilai 0 ; nilai di bawah 1,2 maka perusahaan digolongkan sebagai perusahaan tidak sehat dan diberi nilai -1 (Altman 1968).

Current ratio digunakan untuk mengukur kemampuan perusahaan memenuhi kewajiban jangka pendeknya. Current ratio sama dengan aset lancar dibagi dengan liabilitas lancar. Rasio ini pernah digunakan dalam penelitian Setiawati dan Agoes (2005) dan Mutchler (1984) dalam penelitian Manao dan Nursetyo (2002).

Quick ratio digunakan untuk mengukur seberapa cepat aktiva lancar perusahaan tanpa memperhitungkan persediaan dapat menutupi kewajibanlancar perusahaan. Rasio ini pernah digunakan dalam penelitian Setiawati dan Agoes (2005) dan Hani et al. (2003).

Cash flow from operations digunakan untuk melihat kemampuan perusahaan dalam melakukan kegiatan operasinya terhadap total hutang yang ada di perusahaan. Cash flow from operattions sama dengan aset lancar dibagi dengan total liabilitas. Rasio ini pernah digunakan Mutchler (1984) dalam penelitian Manao dan Nursetyo (2002).

Return on Assets digunakan untuk mengukur kemampuan perusahaan dalam memperoleh atau menghasilkan laba. Semakin besar rasio ini semakin baik, hal ini berarti cepatnya perputaran aktiva dan diperolehnya laba. Rasio ini pernah digunakan dalam penelitian Setiawati dan Agoes (2005), Hani et al. (2003), Komalasari (2004) dan Petronela (2004).

Debt to equity menggambarkan sejauh mana modal pemilik dapat menutupi hutang-hutang kepada pihak luar. Semakin kecil rasio ini semakin 
baik untuk menilai ketersediaannya modal perusahaan. Rasio ini pernah digunakan dalam penelitian Setiawati dan Agoes (2005).

Long term debt to total assets untuk melihat berapa besar porsi hutang jangka panjang dibanding dengan aktiva. Supaya aman porsi hutang jangka panjang terhadap aktiva harus lebih kecil. Rasio ini pernah digunakan dalam penelitian Setiawati dan Agoes (2005) dan Mutchler (1984) dalam penelitian Manao dan Nursetyo (2002).

Debt to total assets menggambarkan sejauh mana hutang dapat ditutupi oleh aktiva. Supaya perusahaan aman porsi hutang harus lebih kecil dari aktiva yang dimiliki perusahaan. Rasio ini pernah digunakan Mutchler (1984) dalam penelitian Manao dan Nursetyo (2002).

Kualitas audit merupakan kualitas atas jasa yang diberikan auditor kepada kliennya. Kualitas audit ini dapat dilihat dari kompetensi dan tingkat independensi seorang auditor. Menurut Ramadhany (2004), variabel ini diukur dengan menggunakan skala nominal, dengan menggunakan variabel dummy, yaitu (1) Perusahaan yang diaudit oleh auditor yang bekerja di KAP yang berafiliasi dengan KAP Big Four diberi nilai “1” (2) Perusahaan yang diaudit oleh auditor yang bukan bekerja di KAP yang berafiliasi dengan KAP Big Four diberi nilai "0".

Opini audit tahun sebelumnya didefinisikan sebagai opini audit yang diterima oleh perusahaan pada tahun sebelumnya. Variabel ini diukur dengan menggunakan variabel dummy, opini audit going concern diberi nilai 1 sedangkan opini audit non-going concern diberi nilai 0 . Variabel ini pernah digunakan dalam penelitian Setyarno et al. (2007) dan Ramadhany (2004).

Debt default atau kegagalan membayar hutang didefinisikan sebagai kelalaian atau kegagalan perusahaan untuk membayar hutang pokok atau bunganya pada saat jatuh tempo (Chen dan Church 1992). Variabel ini diukur dengan menggunakan variabel dummy, angka 1 untuk debt default, angka 0 untuk tidak debt default. Untuk menunjukkan apakah perusahaan dalam keadaan default atau tidak sebelum pengeluaran opini audit.

Pengukuran opinion shopping menggunakan metoda yang diterapkan oleh Lennox (2002). Opinion shopping menunjukkan pergantian auditor independen untuk tahun berikutnya apabila tahun berjalan perusahaan mendapatkan opini audit going concern. Variabel ini diukur dengan menggunakan variabel dummy, angka 1 untuk perusahaan diaudit oleh auditor independen yang berbeda untuk tahun selanjutnya setelah perusahaan mendapatkan opini audit going concern, angka 0 untuk perusahaan diaudit oleh auditor independen yang sama untuk tahun selanjutnya setelah perusahaan mendapatkan opini audit going concern. 


\section{HASIL PENELITIAN}

Berdasarkan analisa statistik deskriptif dapat diperoleh dan diketahui jumlah sampel yang diteliti, nilai maksimum, nilai minimum, rata-rata, dan deviasi standar. Dari data yang ada diperoleh nilai statistik deskriptif sebagai berikut:

Tabel 2 Statistik Deskriptif

\begin{tabular}{lcrrrr}
\hline \multicolumn{1}{c}{ Variabel } & n & Rerata & $\begin{array}{c}\text { Deviasi } \\
\text { Standar }\end{array}$ & Minimal & Maksimal \\
\hline GCAR & 260 & 0,42 & 0,495 & 0 & 1 \\
KONKEU & 260 & $-0,492$ & 0,753 & -1 & 1 \\
CR $(\%)$ & 260 & 185,801 & 253,441 & 10,700 & 3434,760 \\
QR & 260 & 2,900 & 18,835 & 0,011 & 290,530 \\
CFO & 260 & 2,682 & 18,209 & 0,012 & 290,530 \\
ROA (\%) & 260 & $-1,118$ & 16,449 & $-111,930$ & 42,360 \\
DER & 260 & 3,103 & 11,647 & $-68,980$ & 83,630 \\
LDA & 260 & 0,235 & 0,378 & 0 & 2,544 \\
DAR & 260 & 0,961 & 4,497 & 0,05 & 72,730 \\
KUAD & 260 & 0,377 & 0,485 & 0 & 1 \\
OPINSEB & 260 & 0,431 & 0,496 & 0 & 1 \\
DEBTDEF & 260 & 0,469 & 0,500 & 0 & 1 \\
OPSHOP & 260 & 0,45 & 0,498 & 0 & 1 \\
\hline
\end{tabular}

Pada Block Number 0, nilai -2 Log Lokelihood adalah 354,25, sedangkan pada Block Number 1 nilai -2 Log Likehood turun menjadi 160,73. Penurunan sebesar 193,52 dengan tingkat signifikan 0,000 menunjukkan bahwa model pada penelitian ini fit dengan data. Nilai Nagelkerke $R$ Square sebesar 0,706 yang berarti bahwa variasi variabel dependen opini audit going concern dapat dijelaskan oleh variasi variabel independen, yaitu current ratio, quick ratio, cash flow from operations, debt to equity, long term debt to total assets, debt to total assets, return on assets, kualitas audit, opini audit tahun sebelumnya, kondisi keuangan, debt default dan opinion shopping sebesar 70,6\%, sedangkan sisanya, yaitu 29,4\% dijelaskan oleh variasi variabel-variabel lain yang tidak dimasukan ke dalam model penelitian.

Nilai statistik Hosmerlemeshow's Goodness of Fit Test sebesar 4,615 dengan tingkat signifikan 0,798 yang nilainya lebih besar dari 0,05 , dapat dinyatakan bahwa model mampu memprediksi nilai observasi dalam penelitian. Setelah menilai overall model fit terhadap data, selanjutnya dilakukan uji ketepatan prediksi yang dilihat dari tabel klasifikasi. Menurut Ghozali 
(2006, 234) menghitung nilai estimasi yang benar (correct) dan salah (incorrect). Kolom pertama pada tabel klasifikasi merupakan dua nilai prediksi dari variabel dependen, sedangkan pada baris menunjukkan nilai observasi sesungguhnya dari variabel dependen.

\section{Tabel 3 Klasifikasi}

\begin{tabular}{|c|c|c|c|}
\hline \multicolumn{4}{|c|}{ Prediksi Opini Audit } \\
\hline & Non Going Concern & Going Concern & Koreksi (\%) \\
\hline \multicolumn{4}{|l|}{ Observasi } \\
\hline Opini Audit Non Going Concern & 135 & 15 & 90,0 \\
\hline Going Concern & 16 & 94 & 85,5 \\
\hline Keseluruhan & & & 88,1 \\
\hline
\end{tabular}

Hasil pengujian regresi logistik disajikan pada tabel berikut:

Tabel 4 Variabel dalam Persamaan

\begin{tabular}{lrll}
\hline Viariabel & \multicolumn{1}{c}{ B } & S.E. & Sig. \\
\hline Konstanta & $-3,654$ & 0,845 & 0,000 \\
Kondisi keuangan & $\mathbf{- 0 , 8 0 8}$ & $\mathbf{0 , 3 3 8}$ & $\mathbf{0 , 0 1 7}$ \\
Current ratio & 0,001 & 0,002 & 0,743 \\
Quick ratio & $-0,065$ & 0,067 & 0,336 \\
Quick ratio & 0,064 & 0,068 & 0,348 \\
Return on assets & $\mathbf{- 0 , 0 8 1}$ & $\mathbf{0 , 0 2 9}$ & $\mathbf{0 , 0 0 5}$ \\
Debt to equity & 0,010 & 0,015 & 0,501 \\
Long term debt to total assets & $-0,460$ & 0,964 & 0,633 \\
Debt to total assets & $\mathbf{1 , 5 8 0}$ & $\mathbf{0 , 7 9 8}$ & $\mathbf{0 , 0 4 8}$ \\
Kualitas audit & $-0,008$ & 0,439 & 0,985 \\
Opini audit tahun sebelumnya & $\mathbf{3 , 6 7 1}$ & $\mathbf{0 , 4 3 9}$ & $\mathbf{0 , 0 0 0}$ \\
Debt default & 0,215 & 0,444 & 0,628 \\
Opinion shopping & $-0,177$ & 0,438 & 0,686 \\
\hline
\end{tabular}

Dari Tabel 4 dapat dilihat nilai koefisien regresi dan signifikansi untuk setiap variabel independen yang digunakan untuk menjawab hipotesis. Nilai koefisien variabel kondisi keuangan adalah $-0,808$ dengan signifikansi 0,017 di bawah 0,05 sehingga $\mathrm{H}_{1}$ terdukung yang berarti bahwa kondisi keuangan perusahaan yang buruk membuat auditor cenderung memberikan opini audit going concern. Hal ini konsisten dengan hasil penelitian Setyarno et al. (2007), Santoso dan Wedari (2007) serta Rudyawan dan Badera (2009) yang menyatakan bahwa auditor hanya memberikan opini audit going concern 
jika kondisi keuangan perusahaan mengalami kesulitan untuk melanjutkan kelangsungan usahanya.

Nilai koefisien variabel current ratio adalah 0,001 dengan signifikansi 0,743 di atas 0,05 sehingga $\mathrm{H}_{2}$ tidak terdukung yang berarti bahwa current ratio tidak mempengaruhi auditor untuk memberikan opini audit going concern. Hal ini menunjukkan bahwa auditor dalam memberikan opini audit going concern tidak berdasarkan kemampuan perusahaan untuk memenuhi kewajiban jangka pendeknya, akan tetapi lebih cenderung melihat kondisi keuangan perusahaan secara keseluruhan. Current ratio tidak dapat dijadikan tolok ukur yang pasti untuk menentukan going concern atau kelangsungan hidup suatu perusahaan. Namun current ratio dapat menjadi alat bantu dalam pengukuran kondisi keuangan perusahaan (Hani et al. 2003).

Nilai koefisien variabel quick ratio adalah $-0,065$ dengan signifikansi 0,336 di atas 0,05 sehingga $\mathrm{H}_{3}$ tidak terdukung yang berarti bahwa quick ratio tidak mempengaruhi auditor untuk memberikan opini audit going concern. Hal ini menunjukkan bahwa auditor dalam memberikan opini audit going concern tidak berdasarkan seberapa cepat aktiva lancar perusahaan tanpa memperhitungkan persediaan dapat menutupi kewajiban perusahaan, akan tetapi lebih cenderung melihat kondisi keuangan perusahaan secara keseluruhan. Quick ratio tidak dapat dijadikan tolok ukur yang pasti untuk menentukan going concern atau kelangsungan hidup suatu perusahaan. Namun quick ratio dapat menjadi alat bantu dalam pengukuran kondisi keuangan perusahaan (Hani et al. 2003).

Nilai koefisien variabel cash flow from operations (CFO) adalah 0,064 dengan signifikansi $0,348 \mathrm{di}$ atas 0,05 sehingga $\mathrm{H}_{4}$ tidak terdukung yang berarti bahwa cash flow from operations tidak mempengaruhi auditor untuk memberikan opini audit going concern. Hal ini menunjukkan bahwa auditor dalam memberikan opini audit going concern tidak berdasarkan kemampuan perusahaan untuk melakukan kegiatan operasinya terhadap total hutang yang ada di perusahaan, akan tetapi lebih cenderung melihat kondisi keuangan perusahaan secara keseluruhan. Flow from operations tidak dapat dijadikan tolok ukur yang pasti untuk menentukan going concern atau kelangsungan hidup suatu perusahaan. Namun flow from operations dapat menjadi alat bantu dalam pengukuran kondisi keuangan perusahaan (Hani et al. 2003).

Nilai koefisien variabel return on assets adalah -0,081 dengan signifikansi 0,005 di bawah 0,05 sehingga $\mathrm{H}_{5}$ terdukung yang berarti bahwa return on assets yang rendah membuat auditor cenderung memberikan opini audit going concern. Hasil penelitian ini konsisten dengan hasil penelitian Komalasari (2004), Petronela (2004) dan Hani et al. (2003) yang menyata- 
kan bahwa profitabilitas perusahaan dipertimbangkan oleh auditor dalam memberikan opini audit atas laporan keuangan perusahaan.

Nilai koefisien variabel debt to equity adalah 0,01 dengan signifikansi 0,501 di atas 0,05 sehingga $\mathrm{H}_{6}$ tidak terdukung yang berarti bahwa debt to equity tidak mempengaruhi auditor untuk memberikan opini audit going concern. Hal ini menunjukkan bahwa auditor dalam memberikan opini audit going concern tidak berdasarkan sejauh mana modal pemilik dapat menutupi hutang kepada pihak luar, akan tetapi lebih cenderung melihat kondisi keuangan perusahaan secara keseluruhan. Debt to equity perusahaan kurang dipertimbangkan oleh auditor dalam memberikan opini audit atas laporan keuangan perusahaan (Petronela 2004).

Nilai koefisien variabel long term debt to total assets adalah $-0,460$ dengan signifikansi 0,633 di atas 0,05 sehingga $\mathrm{H}_{7}$ tidak terdukung yang berarti bahwa long term debt to total assets tidak mempengaruhi auditor untuk memberikan opini audit going concern. Hal ini menunjukkan bahwa auditor dalam memberikan opini audit going concern tidak berdasarkan besarnya porsi hutang jangka panjang dibanding dengan aktiva, akan tetapi lebih cenderung melihat kondisi keuangan perusahaan secara keseluruhan. Long term debt to total assets tidak dapat dijadikan tolok ukur yang pasti untuk menentukan going concern atau kelangsungan hidup suatu perusahaan. Namun long term debt to total assets dapat menjadi alat bantu dalam pengukuran kondisi keuangan perusahaan (Hani et al. 2003).

Nilai koefisien variabel debt to total assets adalah 1,580 dengan signifikansi 0,048 di bawah 0,05 sehingga $\mathrm{H}_{8}$ terdukung yang berarti bahwa debt to total assets yang tinggi membuat auditor cenderung memberikan opini audit going concern. Perusahaan dengan nilai aset lebih kecil daripada hutangnya akan menghadapi bahaya kebangkrutan. Hal ini dapat menimbulkan ketidakpastian kelangsungan hidup perusahaan dan berpeluang untuk mendapatkan opini audit going concern (Rudyawan dan Badera 2009).

Nilai koefisien variabel kualitas audit adalah $-0,008$ dengan signifikansi 0,985 di atas 0,05 sehingga $\mathrm{H}_{9}$ tidak terdukung yang berarti bahwa kualitas audit tidak berpengaruh terhadap pemberian opini auditor going concern. Hal ini menunjukkan bahwa Kantor Akuntan Publik, baik yang berskala besar maupun yang berskala kecil, akan selalu bersikap obyektif dalam memberikan pendapat going concern kepada perusahaan yang mengalami keraguan dalam kelangsungan hidup usahanya. Hasil penelitian ini konsisten dengan hasil penelitian Rudyawan dan Badera (2009), Santoso dan Wedari (2007), Setyarno et al. (2007), Ramadhany (2004), Komalasari (2004) yang menyatakan bahwa kualitas audit tidak berpengaruh terhadap pemberian opini audit. 
Nilai koefisien variabel opini audit tahun sebelumnya adalah 3,671 dengan signifikan 0,000 di bawah 0,05 sehinggan $\mathrm{H}_{10}$ terdukung yang berarti bahwa auditor cenderung memberikan opini audit going concern yang sama dengan opini audit tahun sebelumnya. Hal ini konsisten dengan hasil penelitian Setyarno et al. (2007), Santoso dan Wedari (2007), Rahayu (2007) dan Ramadhany (2004) yang menyatakan bahwa apabila pada tahun sebelumnya auditor telah menerbitkan opini audit going concern, semakin besar kemungkinan auditor untuk menerbitkan kembali opini audit going concern pada tahun berikutnya. Hal ini menunjukkan bahwa auditor dalam memberikan opini audit akan mempertimbangkan opini audit tahun sebelumnya.

Nilai koefisien variabel debt default adalah 0,215 dengan signifikansi 0,628 di atas 0,05 sehingga $\mathrm{H}_{11}$ tidak terdukung yang berarti bahwa debt default tidak berpengaruh terhadap pemberian opini audit going concern. Hal ini menunjukkan bahwa auditor dalam memberikan opini audit going concern tidak berdasarkan kegagalan perusahaan untuk membayar hutang pokok atau bunganya pada saat jatuh tempo, akan tetapi lebih cenderung melihat kondisi keuangan perusahaan secara keseluruhan.

Nilai koefisien variabel opinion shopping adalah -0,177 dengan signifikansi 0,686 di atas 0,05 sehingga $\mathrm{H}_{12}$ tidak terdukung yang berarti bahwa opinion shopping tidak berpengaruh terhadap pemberian opini audit going concern. Hasil penelitian ini konsisten dengan hasil penelitian Praptitorini dan Januarti (2007) yang menyatakan bahwa perusahaan cenderung menggunakan auditor independen yang sama apapun opini audit yang diberikan, karena perusahaan enggan untuk mengganti auditor independen. Hal ini terlihat dari terbitnya peraturan tentang lamanya penggunaan auditor independen selama tiga tahun dan Kantor Akuntan Publik selama lima tahun. Bukti empiris ini menunjukkan indikasi kurangnya independensi auditor di Indonesia.

\section{PENUTUP}

Berdasarkan hasil pengujian hipotesis dapat disimpulkan bahwa (1) $\mathrm{H}_{1}$ terdukung yang berarti bahwa kondisi keuangan perusahaan yang buruk membuat auditor cenderung memberikan opini audit going concern; (2) $\mathrm{H}_{2}$ tidak terdukung yang berarti bahwa current ratio tidak mempengaruhi auditor untuk memberikan opini audit going concern; (3) $\mathrm{H}_{3}$ tidak terdukung yang berarti bahwa quick ratio tidak mempengaruhi auditor untuk memberikan opini audit going concern; (4) $\mathrm{H}_{4}$ tidak terdukung yang berarti bahwa cash flow from operations tidak mempengaruhi auditor untuk memberikan 
opini audit going concern; (5) $\mathrm{H}_{5}$ terdukung yang berarti bahwa return on assets yang rendah membuat auditor cenderung memberikan opini audit going concern; (6) $\mathrm{H}_{6}$ tidak terdukung yang berarti bahwa debt to equity tidak mempengaruhi auditor untuk memberikan opini audit going concern; (7) $\mathrm{H}_{7}$ tidak terdukung yang berarti bahwa long term debt to total assets tidak mempengaruhi auditor untuk memberikan opini audit going concern; (8) $\mathrm{H}_{8}$ terdukung yang berarti bahwa debt to total assets yang tinggi membuat auditor cenderung memberikan opini audit going concern; (9) $\mathrm{H}_{9}$ tidak terdukung yang berarti bahwa kualitas audit tidak berpengaruh terhadap pemberian opini auditor going concern; (10) $\mathrm{H}_{10}$ terdukung yang berarti bahwa auditor cenderung memberikan opini audit going concern yang sama dengan opini audit tahun sebelumnya; (11) $\mathrm{H}_{11}$ tidak terdukung yang berarti bahwa debt default tidak berpengaruh terhadap pemberian opini audit going concern; (12) $\mathrm{H}_{12}$ tidak terdukung yang berarti bahwa opinion shopping tidak berpengaruh terhadap pemberian opini audit going concern.

Implikasi penelitian ini adalah (1) Memberikan informasi kepada investor tentang manfaat rasio keuangan sebagai alat untuk memprediksi kelangsungan hidup suatu perusahaan publik yang terdaftar di Bursa Efek Indonesia; (2) Dengan adanya pengungkapan atas going concern perusahaan yang dinyatakan dalam bentuk opini audit, maka pihak manajemen akan berusaha untuk mempertahankan kelangsungan hidup perusahaannya serta berupaya untuk meningkatkan kinerja perusahaan; (3) Dengan melihat kondisi keuangan dan kemampuan perusahaan dalam melunasi hutang maka kreditur dapat memutuskan apakah akan memberikan pinjaman dan menentukan kebijakan untuk mengawasi pinjaman yang telah diberikan.

Beberapa keterbatasan dalam melakukan penelitian ini, antara lain (1) Jumlah sampel perusahaan yang dijadikan obyek penelitian hanya satu jenis industri saja, yaitu manufaktur, sehingga tidak dapat mencakup semua hasil temuan untuk seluruh perusahaan publik; (2) Jumlah tahun pengamatan yang terbatas hanya 4 tahun (2005-2008). Untuk memprediksi pemberian opini audit going concern akan lebih baik apabila dilakukan pengamatan dalam jangka waktu yang cukup panjang; (3) Penelitian ini hanya menggunakan 12 variabel independen, yaitu kondisi keuangan, current ratio, quick ratio, cash flow from operations, return on assets, debt to equity, long term debt to total assets, debt to total assets, kualitas audit, opini audit tahun sebelumnya, debt default dan opinion shopping dalam mempengaruhi auditor untuk memberikan opini audit going concern. Auditor dalam memberikan opini audit going concern dapat dipengaruhi oleh faktor lainnya.

Dengan adanya keterbatasan dalam penelitian ini, maka untuk penelitian yang akan datang disarankan untuk (1) Menambah populasi perusahaan 
dari semua jenis industri yang ada di Bursa Efek Indonesia; (2) Menambah jumlah tahun pengamatan, tidak hanya empat tahun, tapi 10 tahun; (3) Menggunakan faktor lain dalam mempengaruhi auditor untuk memberikan opini audit going concern, seperti ukuran perusahaan, pertumbuhan perusahaan, dan keahlian serta independensi auditor.

\section{REFERENSI:}

Altman, Edward I. 1968. Financial Ratios: Discriminan Analysis and The Prediction of Coporate Bankruptey: Journal of Finance Edition 123 September.

Altman, E. dan T. McGough. 1974. Evaluation of A Company as A Going Concern. Journal of Accountancy. Desember, Hlm. 50-57.

Arens, Alvin A., Randal J. Elder dan Mark S. Beasley. 2006. Auditing and Assurance Service. USA: Pearson Education International.

Belkaoui, Ahmed Riahi. 2004. Accounting Theory. USA: Thomson Learning.

Carcello, Joseph V., Roger H. Hermanson dan Neal T. McGrath. 1992. Audit Quality Attributes: The Perception of Audit Partners, Prepares \& Financial Statement Users. Auditing: A Journal of Practice and Theory, Hlm. 1-15.

Chen, K.C. dan B.K. Church. 1992. Default on Debt Obligations and The Issuance of Going-Concern Report. Auditing: Journal Practice and Theory Fall. Hlm. 30-49.

Ghozali, Imam. 2006. Aplikasi Analisis Multivariate dengan Program SPSS. Semarang: Badan Penerbit Universitas Diponegoro.

Gray, Iain dan Stuart Manson. 2000. The Audit Process, Principles, Practice and Cases. Second Edition. USA: Thomson Learning.

Hani, Clearly dan Muklasin. 2003. Going Concern dan Opini Audit: Suatu Studi Pada Perusahaan Perbankan di BEJ. Prosiding Simposium Nasional Akuntansi VI, Surabaya, 16-17 Oktober, Hlm. 1221-1233.

Harahap, Sofyan Syafri. 2005. Teori Akuntansi. Jakarta: PT. Raja Grafindo Persada. 2007. Analisis Kritis Atas Laporan Keuangan, Edisi 1, Jakarta: PT Raja Grafindo Persada.

Institut Akuntan Publik Indonesia. 2001. Standar Profesional Akuntan Publik Per 1 Januari. Jakarta: Salemba Empat.

Jensen, M.C. dan Meckling, W.H. 1976. Theory of the Firm, Managerial Behaviour, Agency Costs and Ownership Structure. Journal of Financial Economics, Vol 3 October, Hlm. 305-360.

Komalasari, Agrianti. 2004. Analisis Pengaruh Kualitas Auditor dan Proxy Going Concern Terhadap Opini Auditor. Jurnal Akuntansi dan Keuangan, Vol. 9, No. 2, Hlm. 1-15.

Lenard, Mary Jane, Perualz Alam dan David Booth. 1998. An Analysis of Fuzzy Clustering and a Hybrid Model for Auditor's Going Concern.

Lennox, C. 2002. Opinion Shopping and Audit Committees.

Manao H. dan Y. Nursetyo, 2002. An Audit Quality Comparison Between Large and Small CPA Firms in Indonesia in the Context of Going Concern Opinion: Evidence Based on Auditees Financial Ratios, Simposium Nasional Akuntansi V, Semarang, Hlm. 36-44. 
Messier, William F., Steven M. Glover dan Douglas F. Prawitt. 2005. Jasa Audit dan Assurance Pendekatan Sistematis. Jakarta: Salemba Empat.

Mutchler, J.F. 1984. Auditor's Perceptions of Going Concern Opinion Decision. Auditing: A Journal of Practice \& Theory. Spring. Hlm. 17-30.

Mutchler, J.F., W. Hopwood dan J.C McKeown. 1997. The Influence of Contrary Information and Mitigating Factors on Audit Report Decisions on Bankrupt Companies. Journal of accounting Research. Autumn.

Petronela, Thio Anastasia. 2004. Pertimbangan Going Concern Perusahaan dalam Pemberian Opini Audit. BALANCE, 1 Maret, Vol. 1, No. 1, Hlm. 46-55.

Petronela, Thio Anastasia dan Mukhlasin. 2003. Pengaruh Profitabilitas Perusahaan Terhadap Ketepatan Waktu Pelaporan Laporan Keuangan Dengan Opini Audit Sebagai Moderating Variabel. Jurnal Ekonomi dan Bisnis, Vol. 3, No. 1, Hlm. 17-26.

Praptitorini, Mirna Dyah dan Indira Januarti. 2007. Analisis Pengaruh Kualitas Audit, Debt Default dan Opinion Shopping terhadap penerimaan Opini Going Concern. Proceedings Simposium Nasional Akuntansi X, Unhas Makassar, 26-28 Juli, Hlm. $1-27$.

Rahayu, Puji. 2007. Assessing Going Concern Opinion: A Study Based On Financial and Non-Financial Informations (Empirical Evidence of Indonesian Banking Firms Listed on JSX and SSX). Proceedings Simposium Nasional Akuntansi X, Unhas Makassar, 26-28 Juli, Hlm. 1-32.

Ramadhany, Alexander. 2004. Analisis Faktor-Faktor Yang Mempengaruhi Penerimaan Opini Audit Going Concern Pada Perusahaan Manufaktur Yang Mengalami Financial Distress Di Bursa Efek Jakarta. Jurnal Maksi, Vol. 4, Hlm. 146-160.

Rudyawan, Arry P. dan I.D. Nyoman Badera. 2009. Opini Audit Going Concern: Kajian Berdasarkan Model Prediksi Kebangkrutan, Pertumbuhan Perusahaan, Leverage dan Reputasi Auditor. Audi (Jurnal Akuntansi dan Bisnis), Vol. 4, No. 2, Juli, Hlm. 129-138.

Setiawan, Santy. 2006. Opini Going Concern dan Prediksi Kebangkrutan Perusahaan. Jurnal Ilmiah Akuntansi, Vol V No 1. Mei. Hlm. 59-67.

Setiawati, L.W. dan Sukrisno Agoes. 2005. Pengaruh Rasio Keuangan dan Prediksi Kebangkrutan terhadap Opini Audit yang dikeluarkan Auditor. Jurnal Akuntans/Th.IX/ $01 /$ Jan.

Setyarno, Eko Budi, Indira Januarti dan Faisal. 2007. Pengaruh Kualitas Audit, Kondisi keuangan Perusahaan, Opini Audit Tahun Sebelumnya dan Pertumbuhan Perusahaan terhadap Opini Audit Going Concern. Jurnal Akuntansi dan Bisnis, Vol. 7, No. 2, Hlm. 129-140.

Smith, Jay M dan K. Fred Skousen. 1992. Akuntansi Intermediate, Vol. Komprehensif, Edisi Sembilan, Jilid Dua. Jakarta: Penerbit Erlangga.

Teoh, S. 1992. Auditor Independence, Dismissal Threats and the Market Reaction to Auditor Switches. Journal of Accounting Research, 30, Hlm. 1-23.

Yusnitasari, Emila F. dan Doddy Setiawan. 2003. Keahlian dan Independensi Auditor pada Keputusan Going Concern. Jurnal Akuntansi dan Bisnis, Vol. 3, No. 1, Hlm. 66-77. 